\title{
Prevotella nigrescens
}

National Cancer Institute

\section{Source}

National Cancer Institute. Prevotella nigrescens. NCI Thesaurus. Code C86674.

A species of obligately anaerobic, Gram-negative, rod shaped bacteria assigned to the phylum Bacteroidetes. This species is nonmotile, non-spore forming, produces characteristic black pigmented colonies with a cream center on blood agar, fluoresces under UV (360 nm) light, indole positive, lipase negative, digests gelatin, hydrolyzes starch, but not esculin, and produces acid from glucose, dextrin, maltose, and sucrose, but not cellobiose, lactose, amygdalin, arabinose, rhamnose, salicin or xylose. P. nigrescens is part of the normal human oral flora, but is also associated with ging ivitis and periodontitis. 